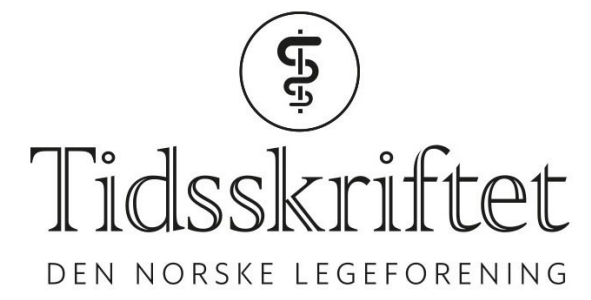

\title{
En fallitterklæring for norske kirurgiske fagmiljøer?
}

DEBATT

\section{PER BRODAL}

E-post: pabrodal@gmail.com

Per Brodal er professor emeritus i medisin (anatomi) ved Institutt for medisinske basalfag, Universitetet i Oslo, med spesialkompetanse innen nevrobiologi og medisinsk utdanning. Forfatteren har fylt ut ICMJE-skjemaet og oppgir ingen interessekonflikter.

Det er fagfolk som må vurdere indikasjon for helsehjelp.

Aftenposten offentligjorde 14. januar i år en liste på 17 kirurgiske inngrep som helseminister Bent Høie ber helseforetakene slutte å bruke eller bruke mindre (1). Begrunnelsen er at man i England er kommet frem til at disse metodene har liten dokumentert effekt. Men også Helse Sør-Øst har, ifølge Høie, sett på bruken av disse metodene og påvist overforbruk. Utfasing ville angivelig tilsvare omtrent halvparten av aktivitetsbudsjettet for et stort sykehus som Sykehuset i Vestfold.

Det foruroliger meg at helseministeren finner det nødvendig å gi helseforetakene spesifikke, faglige anbefalinger. At en prosedyre utføres for ofte, må jo bety at for eksempel kirurgi for karpaltunnelsyndrom i mange tilfeller utføres på feil eller manglende indikasjoner, og at kneartroskopi ved degenerative lidelser utføres i stort omfang til tross for dokumentasjon av manglende effekt. Hva kan så det komme av? Er det kirurgene som ikke er faglig oppdatert og som mangler kritisk, vitenskapelig holdning til eget fag, eller er det $ø$ konomiske motiver som svekker kravene til indikasjonsstilling mot bedre vitende? Uansett er det ingen andre enn fagmiljøene selv som kan rydde opp i overforbruket - ved kritisk å analysere årsaker og drøfte hva som er holdbare indikasjoner for hvert enkelt inngrep. Dette bør følge av faglige retningslinjer i tråd med internasjonale standarder. Hvis ikke fagmiljøene selv tar grep, risikerer vi igjen at overforbruk fortsetter helt til helsemyndighetene oppdager det og så utsteder anbefalinger av typen vi nå ser.

Når fagmiljøene selv ikke tar styringen og rydder opp i egen praksis, kan advarsler om spesifikke prosedyrer spredt til befolkningen føre til at metodene heller ikke brukes der de virkelig er indisert. Jeg vil for eksempel tro at en del fastleger kan komme til å slutte å henvise pasienter som faller innenfor kategoriene helseministeren har "svartelistet», til kirurgisk vurdering. Befolkningen kan også lett sitte igjen med inntrykk av at disse inngrepene aldri skal utføres, og dermed møte faglig korrekte anbefalinger med mistro. Det er ikke bra for tilliten til medisinske fagmiljøer når det kommer frem slike eksempler på manglende evne til å rydde i eget hus. 
LITTERATUR:

1. Dommerud T, Skogstrøm L. Helseministeren ber sykehusene slutte med operasjoner som ikke har effekt. Aftenposten 14.1.2019.

https://www.aftenposten.no/norge/i/VRnjk1/Helseministeren-ber-sykehusene-slutte-med-operasjonersom-ikke-har-effekt (7.2.2019).

Publisert: 11. mars 2019. Tidsskr Nor Legeforen. DOI: 10.4045/tidsskr.19.0113

Mottatt 6.2.2019, godkjent 7.2.2019.

(C) Tidsskrift for Den norske legeforening 2020. Lastet ned fra tidsskriftet.no 